\title{
'Covington' Sweetpotato
}

\author{
G. Craig Yencho ${ }^{1,7}$, Kenneth V. Pecota ${ }^{1}$, and Jonathan R. Schultheis ${ }^{3}$ \\ Department of Horticultural Science, North Carolina State University, \\ Kilgore Hall, Box 7609, 2721 Founders Drive, Raleigh, NC 27695-7609
}

\author{
Zvezdana-Pesic VanEsbroeck ${ }^{2}$ \\ Micropropagation Unit, Department of Plant Pathology, North Carolina \\ State University, Raleigh, NC 27695-7616
}

Gerald J. Holmes ${ }^{1}$

Department of Plant Pathology, North Carolina State University, Raleigh, NC 27695-7616

\author{
Billy E. Little ${ }^{4}$ \\ Wilson County Cooperative Extension Service, 1806 South Goldsboro Street, \\ Wilson, NC 27893
}

Allan C. Thornton ${ }^{5}$
Department of Horticultural Science, North Carolina State University, 55
Agriculture Place, Clinton, NC 28328

Van-Den Truong ${ }^{6}$

USDA ARS Food Science Research Unit, North Carolina State University, Department of Food Science, Raleigh, NC 27695-7624

Additional index words. Ipomoea batatas, Convolvulaceae, cultivar, vegetable breeding, disease resistance, insect resistance, planting density, nitrogen rate

\begin{abstract}
Covington' is an orange-fleshed, smooth-skinned, rose-colored, table-stock sweetpotato [Ipomoea batatas (L.) Lam.] developed by North Carolina State University (NCSU). 'Covington', named after the late Henry M. Covington, an esteemed sweetpotato scientist at North Carolina State, was evaluated as NC98-608 in multiple state and regional yield trials during 2001 to 2006. 'Covington' produces yields equal to 'Beauregard', a dominant sweetpotato variety produced in the United States, but it is typically 5 to 10 days later in maturity. 'Covington' typically sizes its storage roots more evenly than 'Beauregard' resulting in fewer jumbo class roots and a higher percentage of number one roots. Total yields are similar for the two clones with the dry matter content of 'Covington' storage roots typically being 1 to 2 points higher than that of 'Beauregard'. 'Covington' is resistant to fusarium wilt [Fusarium oxysporum Schlect. f.sp. batatas (Wollenw.) Snyd. \& Hans.], southern root-knot nematode [Meloidogyne incognita (Kofoid \& White 1919) Chitwood 1949 race 3], and moderately resistant to streptomyces soil rot [Streptomyces ipomoeae (Person \& W.J. Martin) Wakswan \& Henrici]. Symptoms of the russet crack strain of Sweet Potato Feathery Mottle Virus have not been observed in 'Covington'. The flavor of the baked storage roots of 'Covington' has been rated as very good by standardized and informal taste panels and typically scores as well or better in this regard when compared with 'Beauregard'.
\end{abstract}

'Covington' originated from botanical seed harvested from the sweetpotato clone NC1528 (female parent). NC1528, an NCSU breeding line derived from 'Regal' (Jones

\footnotetext{
Received for publication 14 May 2008. Accepted for publication 3 July 2008.

This research was supported in part by funding from the North Carolina SweetPotato Commission, Inc., the North Carolina Foundation Seed Producers, Inc., and the North Carolina Certified Sweet Potato Seed Growers Association.

${ }^{1}$ Associate Professor.

${ }^{2}$ Researcher.

${ }^{3}$ Professor.

${ }^{4}$ Extension Agent

${ }^{5}$ Extension Associate.

${ }^{6}$ Research Food Technologist and Associate Professor.

${ }^{7}$ To whom reprint requests should be addressed;

e-mail craig_yencho@ncsu.edu
}

typically ranging from two to 15 storage roots with two to 10 storage roots from selected hills being saved for asexual plant propagation the next year. The trial was conducted in Green County near Kinston, NC. 'Covington' was vegetatively increased, evaluated, and advanced as the clone NC98-608 with " 98 " referring to the year in which 'Covington' was selected as a "single-hill" and "608" indicating that 'Covington' was the 608th "single-hill selection" made by the breeding program in 1998. 'Covington' was first recognized as being a potentially competitive commercial cultivar after two further cycles of simultaneous increase and evaluation at the NCDA\&CS Horticultural Crops Research Station, Clinton, NC, and the NCSU Cunningham Research Station, Kinston, NC, during 1999 and 2000.

\section{Description}

The following description of 'Covington' provides standard sweetpotato taxonomic descriptors recommended by the International Potato Center, Asian Vegetable Research \& Development Center, and International Board for Plant Genetic Resources (Huaman, 1991). Color determinations were made using the 2001 Edition of the Royal Horticultural Society (RHS) Color Chart (Royal Horticultural Society, 2001) except where general terms of ordinary dictionary significance are used.

Foliage. 'Covington' has leaves that are cordate to triangular in shape with no to slight lobing. Mature leaves are green, between $147 \mathrm{~A}$ and $147 \mathrm{~B}$ on the upper surface and $147 \mathrm{~B}$ on the lower surface according to the RHS chart with no abaxial or adaxial vein coloration. Young leaf color differs slightly from 'Beauregard' (Rolston et al., 1987) in that 'Covington' has more purple pigmentation than 'Beauregard'. 'Covington' upper and lower leaf surfaces have a green base (147B) with secondary purple (N79A), whereas 'Beauregard' has a green base (147A) with secondary purple (N79B). Petioles are green (144B) with no secondary pigmentation. 'Beauregard' has a purple (N79B) spot at the base of the main rib on the leaf underside, whereas 'Covington' does not. Stems are green and thicker for 'Covington' than 'Beauregard' with less branching. 'Covington' produces a dense, somewhat upright canopy that competes well with weeds.

Flowers. 'Covington' flowers sporadically throughout the season in response to a variety of stressful conditions (e.g., drought, nutrient stress, cloudy weather). The corolla is composed of five fused petals that form a funnel with a pentagonal limb. The flower has slight to no fragrance. The inner and outer limbs of the flower corolla are lavender (76B). The outer throat is lavender (N80B) and the inner throat purple (N80A). Both inner and outer sepals are green (144D and 144C) and ovate with an acute apex. Corolla width averages $4.5 \mathrm{~cm}$ and length $4.3 \mathrm{~cm}$. The stigma is cream-colored (155D) and is 
slightly exerted relative to the stamens. There are five cream (158B) colored anthers that average $2.7 \mathrm{~mm}$ long. Pollen is cream (158B) and produced in moderate amounts. True seed have never been obtained from 'Covington' as a female parent and it is considered female sterile. A few seed have been produced using it as the male parent in controlled crosses, but less than $1 \%$ of the pollinations have been successful. In practical terms, 'Covington' is essentially male sterile. Stained pollen appears normal and the cause of the extremely low fertility is not known.

Storage roots. Storage roots of 'Covington' are oblong, to elliptic, to round elliptic (Figs. 1 and 2). Length/diameter ratio averaged 2:1 for 'Covington' compared with 2:5 for 'Beauregard' averaged over 45 trials in North Carolina. Storage root skin color varies from light to medium rose (33D to 34D) and tends to darken during storage. Flesh color is a uniform orange (28B to 28C) similar to or slightly lighter than 'Beauregard'. Storage root dry matter of 'Covington' averages $19.7 \% \pm 0.3 \%$ compared with $18.7 \% \pm$ $0.3 \%$ for 'Beauregard' when grown in North Carolina.

\section{Disease Reactions}

'Covington' is resistant to southern rootknot nematode (RKN) race 3 . In greenhouse tests, the resistance is greater than resistant 'Jewel' and highly susceptible clones 'Beauregard' and 'Porto Rico'. In tests from 2003, 2004, and 2005, average ratings for RKN egg masses for 'Covington' were 0.7 ('Jewel' = 1.4, 'Beauregard' = 4.1, 'Porto Rico' = 4.3). Egg masses were estimated using a scale of 0 to 5 in which $0=$ no symptoms, $1=$ one to three per plant, $2=$ four to 10 per plant, $3=11$ to 30 per plant, $4=31$ to 100 per plant, and 5 $=$ greater than 100 per plant. The resistance of 'Covington' to southern root-knot nematode race 3 has been independently confirmed by Dr. Judy Thies, USDA-ARS Research Plant Pathologist, U.S. Vegetable Laboratory, Charleston, SC (personal correspondence).

'Covington' is resistant to fusarium wilt or stem rot caused by Fusarium oxysporum. Replicated greenhouse testing and field observations demonstrate that resistance is similar to resistant 'Beauregard' and 'Jewel' and greater than susceptible 'Porto Rico'. 'Covington' is moderately resistant to soil rot, caused by Streptomyces ipomoeae, similar in reaction to resistant 'Beauregard', and much more resistant than susceptible 'Jewel'. Yields in our soil rot disease plot were similar to that of 'Beauregard' with similar incidence of root lesions. Table 1 provides a summary of these three disease screens for 'Covington'.

In terms of postharvest pathogens, 'Covington' is more susceptible to Rhizopus soft rot than 'Beauregard' but slightly more resistant than 'Hernandez' (Edmunds and Holmes, 2008). Russet crack, caused by a strain of Sweet Potato Feathery Mottle Virus (Campbell et al., 1974), has not been observed in 'Covington', although it was

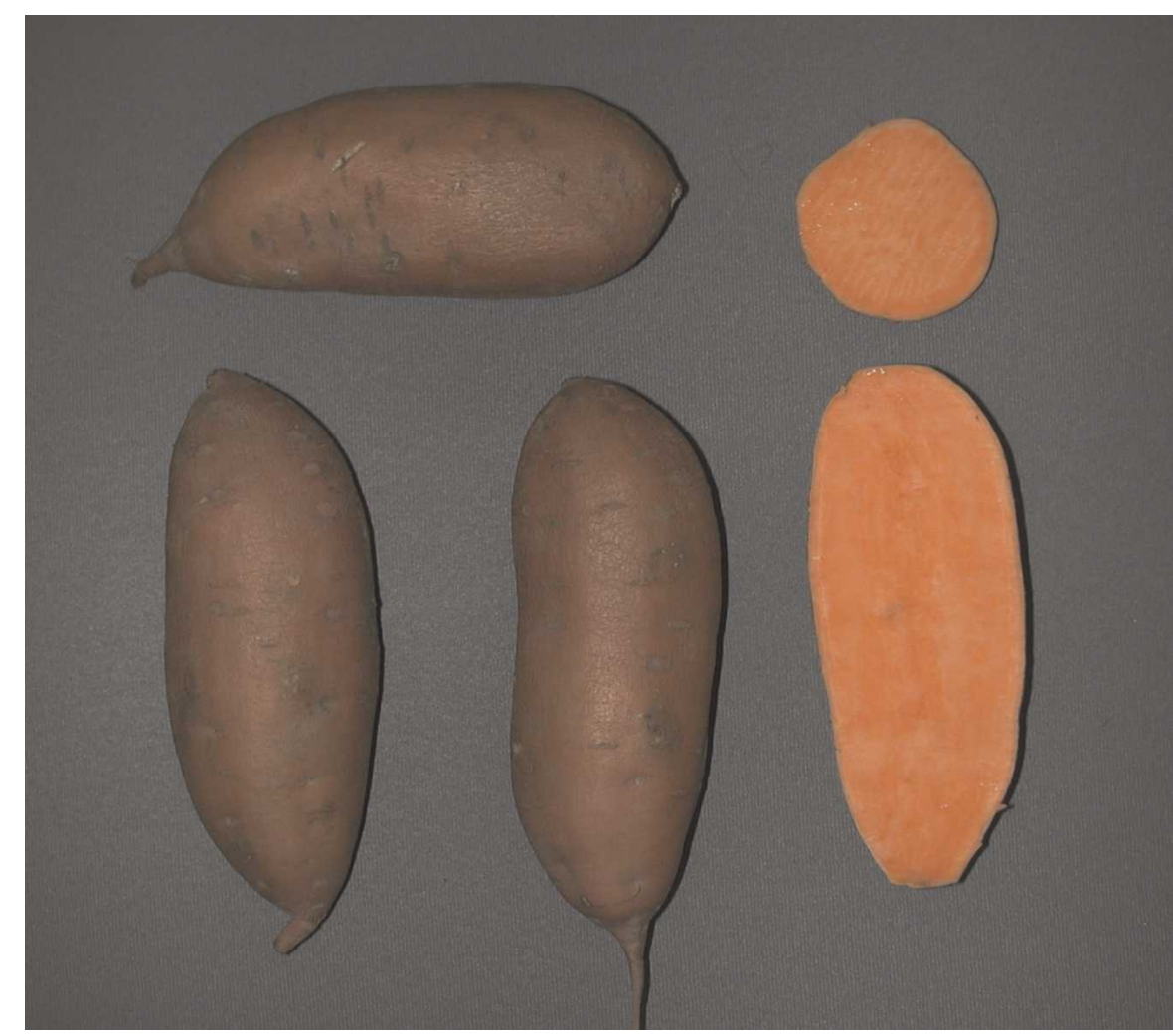

Fig. 1. Typical U.S. No. 1 storage roots of 'Covington'.
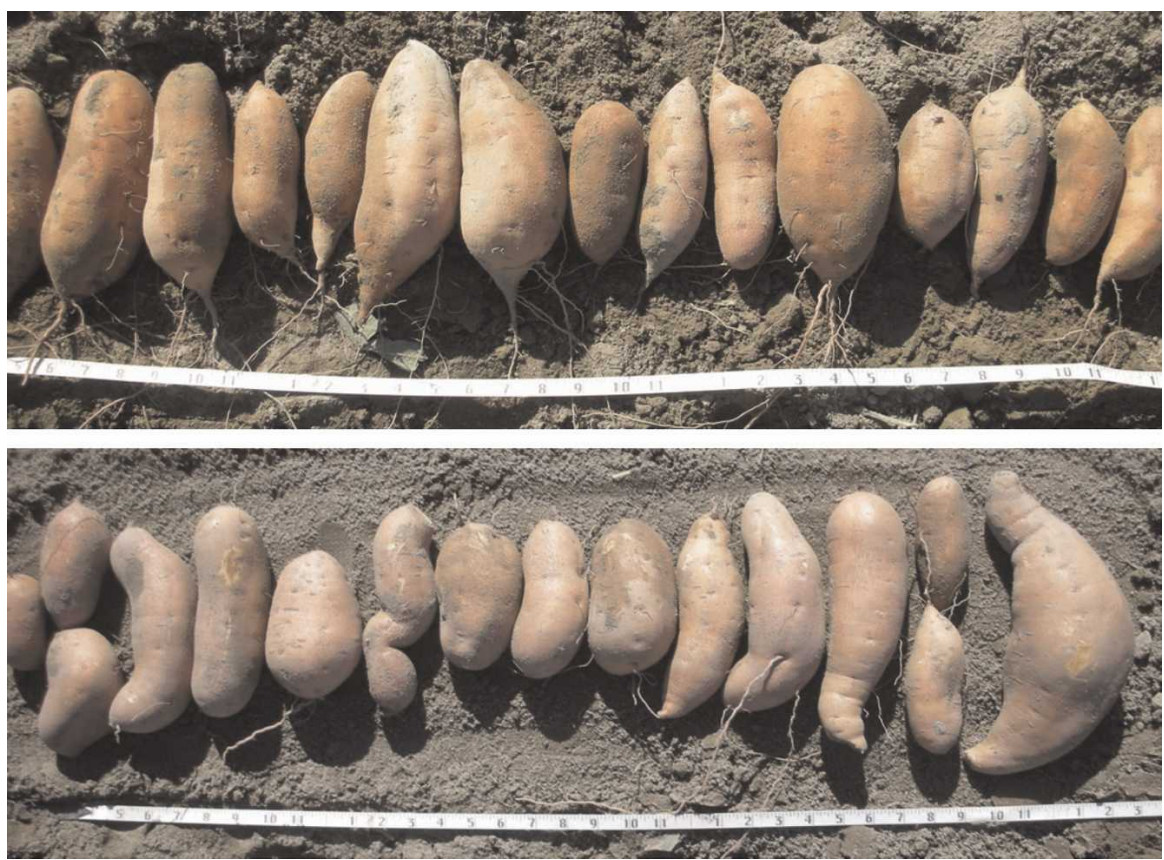

Fig. 2. Comparison of 'Covington' (top) and 'Beauregard' (bottom) storage roots in a 91-cm section of row from an advanced yield trial conducted in Clinton, NC, 2007.

present in 'Beauregard' in numerous trials in North Carolina.

\section{Insect Resistance}

'Covington' was not significantly different from 'Beauregard' in overall percentage of roots damaged or by damage caused by the WDS (Wireworm, Diabrotica, Systena) complex (Schalk et al., 1991) over replicated trials conducted in 2002, 2003, 2004, and 2005. Damage caused by the sweetpotato flea beetle, Chaetocenema confinis Crotch., was significantly lower for 'Covington' than 'Beauregard' (Table 2). 
Table 1. Summary of disease screens of 'Covington' for the years 2000 to 2004.

\begin{tabular}{|c|c|c|c|c|c|c|c|c|c|c|}
\hline \multirow[b]{2}{*}{ Clone } & \multirow[b]{2}{*}{$\mathrm{Yr}$} & \multicolumn{2}{|c|}{ RKN } & \multicolumn{2}{|c|}{ Fusarium wilt } & \multicolumn{2}{|c|}{ SSR GH } & \multicolumn{3}{|c|}{ SSR field } \\
\hline & & $\begin{array}{l}\text { Avg. test } \\
\text { score }\end{array}$ & $\begin{array}{c}\text { Summary } \\
\text { rating }\end{array}$ & $\begin{array}{c}\text { Avg. test } \\
\text { score }\end{array}$ & $\begin{array}{c}\text { Summary } \\
\text { rating }\end{array}$ & $\begin{array}{l}\text { Avg. test } \\
\text { score }\end{array}$ & $\begin{array}{c}\text { Summary } \\
\text { rating }\end{array}$ & Severity & Yield & $\begin{array}{c}\text { Summary } \\
\text { rating }\end{array}$ \\
\hline Covington & 2004 & 0 & HR & 5.7 & $\mathrm{R}$ & 7.7 & $\mathrm{R}$ & 6.3 & 8.3 & $\mathrm{R}$ \\
\hline Porto Rico & & 4 & $\mathrm{~S}$ & 3.5 & $\mathrm{~S}$ & 5 & $\mathrm{~S}$ & 3.3 & 4.3 & $\mathrm{~S}$ \\
\hline Beauregard & & 3.5 & $\mathrm{~S}$ & 5.4 & $\mathrm{R}$ & 8.7 & $\mathrm{R}$ & 5.3 & 8.3 & $\mathrm{R}$ \\
\hline Jewel & & 1 & $\mathrm{R}$ & 3.8 & $\mathrm{R}$ & $\begin{array}{l}2.3 \\
7.7\end{array}$ & $\mathrm{~S}$ & 3 & 5.3 & $\mathrm{~S}$ \\
\hline Covington & 2003 & 0.5 & $\mathrm{R}$ & 2.9 & $\mathrm{R}$ & - & - & - & - & - \\
\hline Porto Rico & & 4 & $\mathrm{~S}$ & 0.5 & $\mathrm{~S}$ & - & - & - & - & - \\
\hline Beauregard & & 4 & $\mathrm{~S}$ & 2.4 & $\mathrm{R}$ & - & - & - & - & - \\
\hline Jewel & & 0.25 & $\mathrm{R}$ & 2.7 & $\mathrm{R}$ & - & - & - & - & - \\
\hline Covington & 2002 & - & - & 3.1 & $\mathrm{R}$ & 5 & MR & 7 & - & $\mathrm{R}$ \\
\hline Porto Rico & & - & - & 0.5 & $\mathrm{~S}$ & 2 & $\mathrm{~S}$ & 4.6 & - & $\mathrm{S}$ \\
\hline Beauregard & & - & - & 2.5 & MR & 7.3 & $\mathrm{R}$ & 8 & - & $\mathrm{R}$ \\
\hline Jewel & & - & - & 3.2 & $\mathrm{R}$ & 2 & $\mathrm{~S}$ & 3 & - & $\mathrm{S}$ \\
\hline Covington & 2000 & - & - & 6.7 & $\mathrm{R}$ & 4 & MS & - & - & - \\
\hline Porto Rico & & - & - & 1.7 & $\mathrm{~S}$ & 2.7 & $\mathrm{~S}$ & - & - & - \\
\hline Beauregard & & - & - & 5.7 & MR & 7.5 & $\mathrm{R}$ & - & - & - \\
\hline Jewel & & - & - & 6.3 & $\mathrm{R}$ & 3.3 & MS & - & - & - \\
\hline
\end{tabular}

RKN = southern root knot nematode, Melodoigyne incognita fusarium wilt = Fusarium oxysporum Schlect. f. sp. batatas; SSR GH = streptomyces soil rot, Streptomyces ipomoeae; greenhouse test; SSR field = streptomyces soil rot, Streptomyces ipomoeae; field test. Resistant (R) and susceptible (S) checks: RKN (Jewel-R, Beauregard—S); Fusarium (Beauregard—R, Porto Rico-S); SSR (Beauregard-R, Jewel—S); HR = highly resistant; MR = medium resistance. RKN rating scale: $0=$ no galls; $1=$ one to three galls; $2=$ four to 10 galls; $3=11$ to 30 galls; $4=31$ to 100 galls; $5=$ greater than 100 galls. Fusarium (2000 and 2004$)$ and SSR disease rating scale: $0=$ dead; $1=$ very severe; $3=$ severe; $5=$ fair; $7=$ good; $9=$ healthy. Fusarium rating scale $(2002$ to 2003$)$ : $0=$ dead; $1=$ very severe symptoms; 2 = vascular browning, wilt, chlorosis, loss of leaves; $3=$ slight wilting and/or chlorosis, slight vascular browning; $4=$ healthy plant with no symptoms.

Table 2. Insect damage of 'Beauregard' and 'Covington' in replicated trials in 2002, 2003, 2004, and 2005 at Kinston, NC.

\begin{tabular}{|c|c|c|c|c|c|c|c|c|c|c|c|c|}
\hline \multirow[b]{2}{*}{ Cultivar } & \multicolumn{4}{|c|}{ Percent roots not damaged } & \multicolumn{4}{|c|}{ WDS severity index } & \multicolumn{4}{|c|}{ SPFB damaged roots $(\%)$} \\
\hline & 2005 & 2004 & 2003 & 2002 & 2005 & 2004 & 2003 & 2002 & 2005 & 2004 & 2003 & 2002 \\
\hline$\overline{\text { Bea }}$ & 2 & 2 & 51 & 11 & 0 & 0.99 & 0.65 & 1. & 27 & 16 & 6 & 50 \\
\hline $\operatorname{cov}$ & 36 & 48 & 49 & 34 & 0.68 & 0.72 & 0.60 & 0.62 & 5 & 4 & 2 & 21 \\
\hline$P$ & NS & NS & NS & 0.0001 & NS & NS & NS & NS & 0.0001 & 0.0001 & NS & 0.000 \\
\hline
\end{tabular}

WDS = wireworm-Diabrotica-Systena complex (Schalk et al., 1991); SPFB = Sweetpotato flea beetle; LSD = least significant difference; $\mathrm{NS}=$ nonsignificant at $P=0.05$.

\section{Plant Bed Performance}

Bedded roots produce similar to fewer sprouts than 'Beauregard'. Plants of 'Covington' derived from transplant beds are typically thicker with the average stem diameter for 'Covington' being $4.1 \mathrm{~mm}$ as compared with 'Beauregard' averaging $3.5 \mathrm{~mm}$ in diameter $(\mathrm{n}=50)$. 'Covington' and 'Beau$\mathrm{mm}$ and $20 \mathrm{~mm}$ in height, respectively; $\mathrm{n}=$ 50) with the same number of nodes per cutting (both producing 8.9 nodes per cutting; $\mathrm{n}=50$ ). During cool transplant production seasons, 'Covington' produces shorter, stockier plants that are ready to cut a week later as compared with 'Beauregard'. Greenhouse plant production of 'Covington' generally lags behind that of 'Beauregard' with the effect lessened under very hot spring conditions.

\section{Root Yield and Grade}

'Covington' was compared with 'Beauwith four or six replications at various locations in North Carolina. There were 36 trials over a period of 6 years (2001 to 2006). These trials covered a wide range of soil types, planting dates, and growing days. Yield and grade of 'Covington' consistently compared regard' produce similar length plants (20.1 regard' in randomized complete block trials orators 2004, 2005, and 2006 yield trials in 11,12 , and nine trials, respectively. 'Covington' averaged lower yields in 2004 and 2005 but higher yields in 2006 (Table 4). 'Covington' shows some regional adaptation, performing better in the southeast and not as well in the deep south areas of Louisiana and Mississippi in these trials when compared with 'Beauregard'.

\section{Cultural Management}

We have examined the effects of in-row spacing and nitrogen rate and application timing on 'Covington' sweetpotato yield and grades in North Carolina. 'Beauregard' yielded best when in-row spacing was close, 15.2 to $22.9 \mathrm{~cm}$ (Schultheis et al., 1999). With 'Covington', when moisture is not limiting, and for earlier harvest [90 d after planting (DAP)], wider 38.1-cm in-row spacing between plants resulted in the most yield compared with $15.2,30.5$, and $38.1 \mathrm{~cm}$. For later harvests (105 to $120 \mathrm{DAP})$, which are more typical, the $30.5-\mathrm{cm}$ in-row spacing resulted in the best yields of marketable
Table 3. Average yield of 'Covington' and 'Beauregard' in replicated yield trials in North Carolinaz.

\begin{tabular}{|c|c|c|c|c|c|c|c|}
\hline \multirow[b]{2}{*}{ Clone } & \multirow{2}{*}{$\begin{array}{l}\text { Total yield } \\
\left(\mathrm{Mt}^{-} \mathrm{ha}^{-1}\right)\end{array}$} & \multicolumn{2}{|c|}{ Marketable yield } & \multicolumn{4}{|c|}{ Size distribution by class ${ }^{\mathrm{y}}(\%$ of total yield $)$} \\
\hline & & $\overline{M t} \cdot h^{-1}$ & $\overline{\% \text { Beau }}$ & No. 1's & Canners & Jumbo's & Culls \\
\hline Covington & 45.3 & 41.5 & 106 & 58 & 24 & 11 & 8 \\
\hline Beauregard & & & & & & & \\
\hline B94-14 & 48.8 & 42.4 & 100 & 54 & 18 & 15 & 13 \\
\hline
\end{tabular}

${ }^{\mathrm{z}}$ Average of three yield tests in 2001, seven in 2002, seven in 2003, six in 2004, six in 2005, and seven in 2006 .

${ }^{y}$ Sizes of roots: U.S. No. 1: 5.1 to $8.9 \mathrm{~cm}$ diameter, 7.6 to $22.9 \mathrm{~cm}$ long; canner: 2.5 to $5.1 \mathrm{~cm}$ diameter, 5.1 to $17.8 \mathrm{~cm}$ long; jumbo: larger than U.S. No. 1 in diameter or length or both and without objectionable defects; culls: larger than $2.5 \mathrm{~cm}$ in diameter and so misshapen or unattractive that they could not fit as marketable roots in any of the previously mentioned three grades. Total yield $=$ marketable yield + culls. Note: \% 'Beauregard' was determined by adding the percentage of 'Beauregard' for each test, then dividing by the number of tests. There were two tests in which 'Covington' was over $200 \%$ of the Beauregard yield; thus, the average is higher averaged this way than if determined on the overall average, which would be $98 \%$. 
Table 4. Average yield by grade of 'Covington' and 'Beauregard' in National Sweetpotato Collaborators regional trials ${ }^{\mathrm{z}}$.

\begin{tabular}{|c|c|c|c|c|c|}
\hline \multirow[b]{2}{*}{ Cultivar } & \multicolumn{5}{|c|}{ Avg yield $\left(\mathrm{Mt}^{\prime} \cdot \mathrm{ha}^{-1}\right)^{y}$} \\
\hline & U.S. No. 1 & Canner & Jumbo & Total Mkt & Cull \\
\hline & & & & & \\
\hline Covington & 17.6 & 8.9 & 5.6 & 32.9 & 2.5 \\
\hline Beauregard & 21.1 & ${ }^{10.1}$ & 9.8 & 41.2 & 2.1 \\
\hline Covington & 15.8 & 9.8 & 3.9 & 29.5 & 1.3 \\
\hline Beauregard & 20.4 & ${ }^{9.7}$ & 4.5 & 33.0 & 2.2 \\
\hline Covington & 19.3 & 8.8 & 3.9 & 32.0 & 2.5 \\
\hline Beauregard & 17.5 & 5.4 & 4.5 & 28.0 & 3.1 \\
\hline
\end{tabular}

${ }^{\mathrm{z}}$ Sizes of roots: U.S. No. $1: 5.1$ to $8.9 \mathrm{~cm}$ diameter, 7.6 to $22.9 \mathrm{~cm}$ long; canner: 2.5 to $5.1 \mathrm{~cm}$ diameter, 5.1 to $17.8 \mathrm{~cm}$ long; jumbo: larger than U.S. No. 1 in diameter or length or both and without objectionable defects; culls: larger than $2.5 \mathrm{~cm}$ in diameter and so misshapen or unattractive that they could not fit as marketable roots in any of the previously mentioned three grades. Total yield $=$ marketable yield + culls . ${ }^{y}$ Statistical treatment of these tests not feasible. Mt $\cdot \mathrm{ha}^{-1} \times 17.84=$ no. of $50 \mathrm{lb}$. bu. per acre.

Table 5. Nutrient components of 'Covington' and 'Beauregard' storage roots.

\begin{tabular}{lcc}
\hline Nutrient components & Covington & Beauregard \\
\hline Dry matter (\%) & 20.0 & 18.7 \\
Ash (\%) & 0.91 & 0.88 \\
Fat (\%) & 0.30 & 0.24 \\
Protein (\%) & 1.8 & 1.4 \\
Total carbohydrates (\%) & 17 & 16.2 \\
Total dietary fiber (\%) & 2.2 & 2.1 \\
Degree Brix & 10.9 & 9.7 \\
Starch (g/100 g & & \\
$\quad$ fresh weight) & 9.5 & 8.9 \\
$\quad$ Total sugars (g/100 g & & \\
$\quad$ fresh weight) & 5.2 & 4.9 \\
Sucrose & 3.8 & 3.4 \\
Reducing sugars (g/100 g & & \\
$\quad$ fresh weight) & 1.4 & 1.6 \\
$\quad$ Glucose & 0.88 & 1.0 \\
Fructose & 0.55 & 0.57 \\
Maltose & $\mathrm{ND}$ & $\mathrm{ND}$ \\
Beta-carotene (mg/100 g & & \\
$\quad$ fresh weight) & 9.1 & 9.5 \\
\hline
\end{tabular}

Note: Harvested roots were cured at $30{ }^{\circ} \mathrm{C}, 80 \%$ to $90 \%$ relative humidity for $7 \mathrm{~d}$.

$\mathrm{ND}=$ not detectable.

U.S. Grade No. 1 roots. In earlier studies, 'Beauregard' has been reported to need limited amounts of nitrogen during the production season $\left[56.0 \mathrm{~kg} \cdot \mathrm{ha}^{-1} \mathrm{~N}(50 \mathrm{lb} /\right.$ acre N)] (Schultheis et al., 1999). However, 'Covington' has been more responsive to higher rates of nitrogen compared with 'Beauregard' because U.S. Grade No. 1 root yields were consistently greater when $100.9 \mathrm{~kg} \cdot \mathrm{ha}^{1}$
(90 lb per acre) were applied versus 0, 33.6, and $67.3 \mathrm{~kg} \cdot \mathrm{ha}^{-1}(30,60$, and $90 \mathrm{lbs}$ per acre), respectively, during the production season. In some cases, 'Covington' roots sized quicker when nitrogen was applied as a split application 10 and 28 DAP rather than as a single application.

\section{Storage}

Roots of 'Covington' store well without excessive weight loss from storage rots or dehydration. In controlled storage environments (relative humidity, $85 \%$; temperature, $15.5^{\circ} \mathrm{C}$ ), roots remain marketable for several months, similar to 'Beauregard'. Baked or canned roots have a good, uniform orange color, slightly lighter in color and darker in tone than 'Beauregard', and both products have very good taste as judged by tests with untrained taste panels.

\section{Chemical and Nutritional Analyses}

Nutrient composition of 'Covington' and 'Beauregard' roots are shown in Table 5. Dry matter content of 'Covington' averaged 20\%, which was slightly higher than that of 'Beauregard'. 'Covington' had higher starch content, ${ }^{\circ}$ Brix, and total sugars. The two cultivars had similar levels of fat, protein, ash, total carbohydrates, dietary fiber, and reducing sugars. Beta-carotene in 'Covington' was $9.1 \mathrm{mg}$ per $100 \mathrm{~g}$ fresh weight and was comparable with the levels of 'Beauregard' and other commercial cultivars.

\section{Availability}

'Covington' was granted Plant Patent status on 26 Feb. 2008 (U.S. Plant Patent No. 18516). Dr. Zvezdana Pesic-VanEsbroeck, Director of the NCSU Micropropagation Unit, Department of Plant Pathology, NC State University, Campus Box 7616, 3709 Hillsborough Street, Raleigh, NC 27695-7616 is in charge of providing virusindexed nuclear planting propagules of ' $\mathrm{Cov}$ ington'. At present, nuclear stocks of ' $\mathrm{Cov}$ ington' are only provided to North Carolina Crop Improvement Association-approved, certified Sweet Potato Seed Producer Association members. Certified seed producers are licensed to provide certified plants and/ or seed roots to growers. A complete listing of certified seed producers can be found at the web site of the NC SweetPotato Commission, Inc. at $<\mathrm{http}: / /$ www.ncsweetpotatoes.com/ $>$ under the "address list" link. Growers interested in obtaining a license to propagate and/ or sell 'Covington' should contact Dr. Daryl Bowman, Professor and Director, NC Foundation Seed Producers, 3709 Hillsborough Street, Box 8604, Raleigh, NC 27695-8604.

\section{Literature Cited}

Campbell, R.N., D.H. Hall, and N.M. Mielinis. 1974. Etiology of sweet potato russet crack disease. Phytopathology 64:210-218.

Edmunds, B.A. and G.J. Holmes. 2008. Susceptibility of sweetpotato tablestock and high dry matter cultigens to Rhizopus soft rot. Plant Dis. Mgt. Rpt. Report no. 2:V146.

Huaman, Z. (ed.). 1991. Descriptors for sweet potato. CIP, AVRDC, IBPGR, Rome, Italy.

Jones, A., P.D. Dukes, J.M. Schalk, M.G. Hamilton, M.A. Mullen, R.A. Baumgardner, D.R. Paterson, and T.E. Boswell. 1985. 'Regal' sweet potato. HortScience 20:781-782.

Rolston, L.H., C.A. Clark, J.M. Cannon, W.M. Randle, E.G. Riley, P.W. Wilson, and M.L. Robbins. 1987 'Beauregard' sweet potato. HortScience 22:13381339.

Royal Horticultural Society. 2001. RHS colour charts. RHS, London, UK.

Schalk, J.M., A. Jones, P.D. Dukes, and J.K. Peterson. 1991. Approaches to the control of multiple insect problems in sweet potato in the southeastern United States, p. 283-301. In: Jansson, R.K. and K.V. Raman (eds.). Sweet potato pest management, a global perspective. Westview Press Inc., Boulder, $\mathrm{CO}$. 